\title{
Water Supply and Hydraulic Devices: the dams in the Umayyad Jordan
}

\author{
Ivan Campana \\ Sapienza, University of Rome \\ ivancampana31@gmail.com
}

\begin{abstract}
Jordan is one of the most water-poor countries in the world. Natural water resources are few and always threatened by the modern activities that are worsening the situation. During the Umayyad period, (661-750 AD) Jordan was part of the Syro-Palestinian territory (Syria, Jordan, Palestinian territories, Lebanon and Israel) that constituted the most important residential area of the caliphate. Despite the scarce of water, the Umayyad transform these arid lands into a flourish garden. This was possible only through an accurate and widespread control of the water resources. Even though these devices had an important role into the Umayyad power, they are still quite unknown. Today, using technology as the GIS or the satellite imagery (Landsat, RSTM) is now possible to study the diffusional pattern of these devices on the territory. The aim is to produce archaeological thematic maps of the Umayyad settlements of Jordan and to study their relationships to the water supply systems in order to attempt to explain their role in connection with the Umayyad power in this region. Among these devices, the dams are the most impressive. This paper represent a preliminary work meant analyze these structures and their connection with the environment and the agriculture making some hypothesis about the irrigation practices linked to them, with the intent of begin to study such essential aspect of the Umayyad power.
\end{abstract}

Keywords: Umayyad, Jordan, water, dam, irrigation.

\section{Introduction}

During the Umayyad period, (661-750 AD) Jordan was part of the Syro-Palestinian territory (Syria, Jordan, Palestinian territories, Lebanon and Israel) that constituted the most important residential area of the caliphate. Despite the arid climate, construction of the Umayyad caliphate in this land (as in the whole Syro-Palestinian territory) was remarkable, as can be seen in the numerous foundations, such as the qusur, which had the dual function of caliph residence and farm, thus requiring a large and constant supply of water.

However, the Jordan territory is extremely poor of water, $70 \%$ of Jordan is classed as semi desert (NRA 1977, brochure issued from Natural Resources Authority of Jordan). Except for the Dead Sea, the Jordan River and some perpetual springs of the Azraq Oasis, there no other relevant water resources. The frequency of rainfall on the territory is varied. An example of the differences can be seen along the Jordan River, where rainfall ranges yearly from $900 \mathrm{~mm}$ in northern Israel to less than $100 \mathrm{~mm}$ on the Dead Sea (Hoff et al., 2011). Despite this lack of water, settlements could be found also in remote lands that are very arid and apparently inhospitable, but that have developed using rainwater, river water, and underground water. Essential instrument to control and develop these arid lands was the suitable management of the little water available (Kennedy, 1995). This was possible using different technical installations and devices as reservoirs, dams, and wells.

In autumn 2011, in order to validate the literary data encountered during the work for the M.A. thesis (Campana, 2011), a ten days field survey was conducted in Jordan. Each hydraulic structure was located according to the information included in the specific publications. This was an important task in order to provide a thematic map of the Umayyad hydraulic structures of Jordan and to study their relations with the contemporaneous 
settlements. A first validation of the positioning was done through the Google Earth ${ }^{\mathrm{TM}}$ satellite imagery, to locate the sites ant to gain the geographical coordinates, and later by a focused fieldwork to analyze some of these structures in order to verify some data and to check the status of the structures. The spatial data were then managed within a GIS frame in order to make easier the data elaboration and the analysis processes. Among the sites surveyed in this preliminary study ('Ayn al-Inuqiyah, 'Amman, Mshatta, Qasr 'Ayn al-Sil, Qusayr 'Amra, Qastal, 'Umm al-Walid, 'Umm al-Jimal, Qasr al-Hallabat) the work focused on 'Umm al-Walid to explore the role of the dams in collecting water and in the irrigation process.

\section{Methodology}

This study follows the researching path marked by the Universitat Autònoma de Barcelona in the sphere of the Medieval Agricultural Archaeology both in the Spain (Kirchner, 2008 Ballesteros Arias et al., 2010; Barceló et al., 1996) both in Yemen (Barceló et al., 2000; 2003; Barceló \& Torró, 2000). To analyze the territory, different instruments had been used. First step was the sites identification using Google Earth ${ }^{\mathrm{TM}}$ satellite imagery and aerial photography ${ }^{1}$. All the images had been then treated with Adobe Photoshop CS5 ${ }^{\mathrm{TM}}$ and this made possible to highlight different aspects of the territory like differences in terrain moisture, agricultural works like traces of irrigation or cultivated fields. Second step was the measurement of the areas using Google Earth $\mathrm{Pro}^{\mathrm{Tm}}$. In addition, a field survey was conducted in 2011 to localize the 'Umm al-Walid dams and all the other hydraulic structures linked to them. However, until now, miss an archeological interventions aimed to some aspect of the hydraulic structures and specific survey to map the irrigated areas.

\section{Umayyad dams}

The dam is the most common method to stop the water flow of a river. It is a structure, transverse to the riverbed, which obstructs the stream in order to create an artificial basin, where the water was gathered and stored with minimum waste.

In Jordan, rivers are rare while the seasonal river dominate the scene taking the appearance of widyan. The wadi (pl. widyan) is a natural riverbed that takes the form of a canyon or a valley in which a seasonal watercourse flows (or flowed). During the heavy rainfall, the water quickly fills the riverbed creating impetuous streams and often results in flash floods. Then, the water collected into the dam basin was used to irrigate the adjacent fields. The main problem of this kind of irrigation is that strictly depends upon these sporadic rainstorms in otherwise arid lands (Hill, 2002).

In addition to 'Umm al-Walid and Qastal, other Umayyad dams are known in Dayr alKhaf, Jabir, Jilat, Khan al-Zabib, Mushash, Qasr al-Tuba, Qasr 'Ayn al-Sil, QasrBurqu, 'Umm al-Jimal, , Wadi al-Baydabut these structures had been analyzed only trough literary or photographic data.

The Umayyad dams so far analyzed seem to belong to the type known as "gravity dam"; there are three basic forms of dam design: the gravity dam, the arched dam and the arch

${ }^{1}$ http://www.apaame.org/ 
dam. A gravity dam is constructed to resist to the pressure both from the water stored in the basin both from the flow. For this reason, the gravity dams are massive and, since the main pressure is focused against their base, they are often wide-based structures in general long and low. The arched dams are very similar to the gravity ones because they follow the same principles. The arch dams works differently: their convex shape allow diverting the incoming energy horizontally and this allow building dams less thick, especially at the base (Hodge, 1992; Kamash, 2006).

The Umayyad dams gravity considered in this study seems show the same basic feature in their structure: two walls, one upstream and another one downstream both built usually with well-squared calcareous stone-blocks filled with mortar and river cobblestone. The upstream side was usually built with rows of stone blocks positioned horizontally on their major axis. The downstream side either could have the shape of a vertical wall, made of horizontal rows of blocks, or with the rows indented creating a characteristic "stepped" surface. The latter solution was likely adopted for increasing the stability and the resistance of the structure itself. Even though the basic structure and the building materials are usually of local origin, every dam shows individual features in term of sluices, overflow devices, channels, buttresses, wedges, plaster, etc.

\section{1 'Umm al-Walid}

The cases here analyzed are the two dams built through the wadi al-Qanatir at 'Umm alWalid. The geographical area in which the settlement was set up, belong to the vast plain rising from the center of the desert where the precipitation are between the 100 and $200 \mathrm{~mm}$ (Abu Shmais, 2007). Despite the region was already populated by the romans ${ }^{2}$ (there are remains of a temple and a mausoleum), if not earlier (during the survey a flintstone has been found), the construction of the site, as the name suggests, seems to be ascribable at the work of the caliph al-Walid (705-715).

The Umayyad site of 'Umm al-Walidis constituted by two related areas: the residential area with a qasr, a mosque (Herzfeld, 1921; King et al., 1981), and other structures and the cultivated area with two dams, cisterns and dikes (Fig.6).

The two dams are located inside the wadi al-Qanatir, two kilometers northeast from the site. The upstream dam is $135 \mathrm{~m}$ long, $6.10 \mathrm{~m}$ width at the base, and $9 \mathrm{~m}$ high (Fig.1). Both the façades are built with horizontal rows of local calcareous stone-blocks. The upstream façade is vertical while the downstream one is stepped. The empty space between the two façades is filled with rough stones and lime mortar mixed with ash. On the downstream side of the 'Umm al-Walid dam, near the right bank, there is a buttress $15 \mathrm{~m}$ long and 1.20 $\mathrm{m}$ thick. It was built up in order to increase the resistance of the structure, especially in case of sudden and devastating floods. An earthen wall, now disappeared, had to have the same function.

Two conduits passing through the dam allowed controlling the downstream water flow by the opening of two sluices. A wide step, situated under the sluices, seems to be a maintenance passage, to clean them from the sediments. On the downstream side, behind the dam, two smalls channels running from both sluices lead the water to the cultivated areas, although today last just few traces.

${ }^{2}$ http://www.discoverislamicart.org/ 


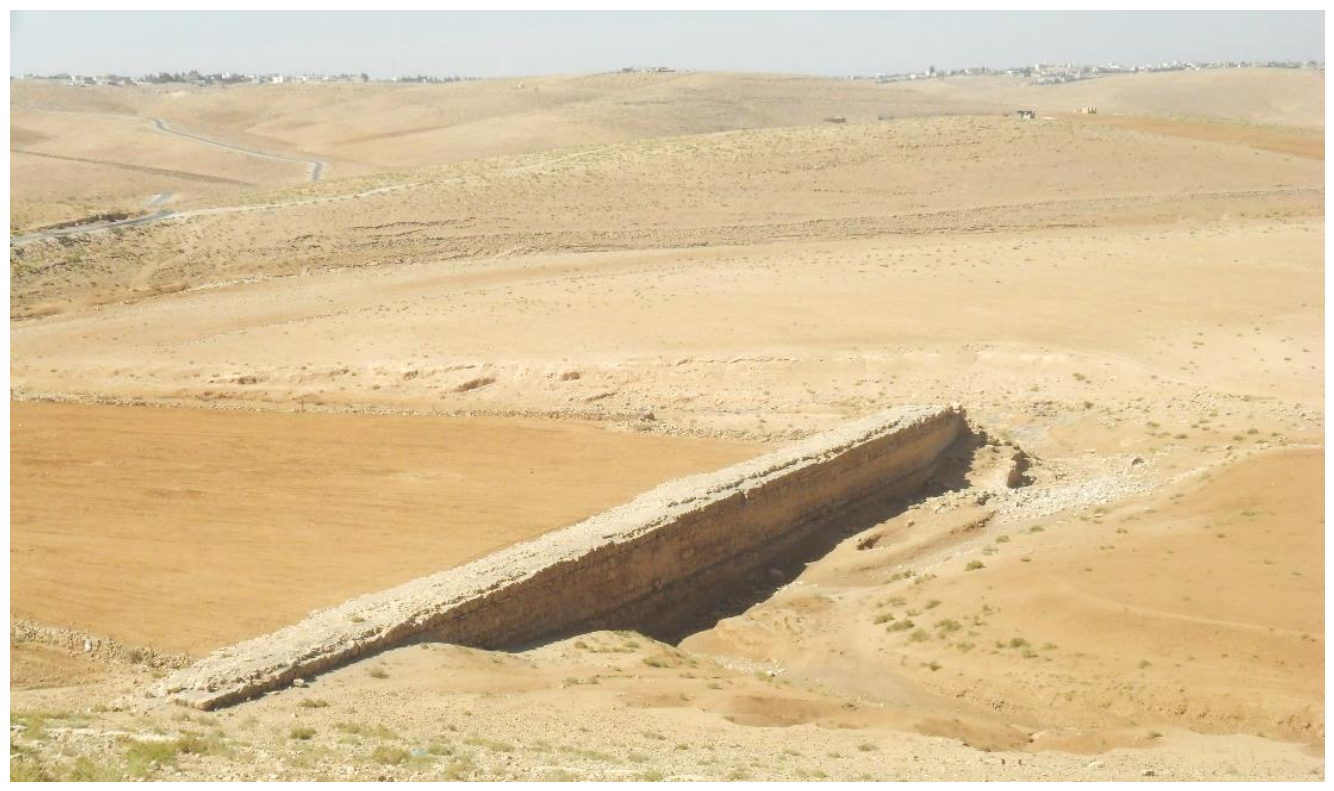

Fig. 1. The upstream dam (Campana, 2011).

One chute spillway was used to provide the controlled release of the overflowing waters, especially during the floods. It has an inclined surface $8 \mathrm{~m}$ longer than the dam, and $3 \mathrm{~m}$ down from the top. On the top of the dam, all along the structure, are still visible some remains. They probably belong to a duct whose function is not clear. On the upper side of the downstream dam, there was the same structure today obliterated by a layer of concrete. About sixteen meters north to the dam, there are remains of a structure, probably a guardian house.

The first dam at 'Umm al-Walid shows also the work of a later remaking. A wall, $3 \mathrm{~m}$ thick, made with large blocks in a row and aligned with stone wedges was added all along the upstream side of the dam. This wall was sealed with three layers of mortar mixed with ash. This particular technique seems to be very similar to the one used for the walls of the eastern qasr of 'Umm al-Walid. The overflow device was also rebuilt in the same place and in the same shape but the threshold was raised over a meter, increasing the storage capacity of the basin but jeopardizing the stability justifying, probably, the reinforcement of the dam.

Noteworthy, in this phase the canals into the dam were extended, as well as the openings on the upstream side, equipped with sluices, were slightly raised to avoid clogging by alluvial deposits. On the upstream side of the dam, along the wadi sides, there are two small dikes, each one approximately $1 \mathrm{~km}$ long; they were made with the same kind of stone used to build the dams ${ }^{3}$.

\footnotetext{
${ }^{3}$ The description it is based both on the analysis made by Bujard and Genequand (2001) and on the observation made during the field survey done in 2011.
} 


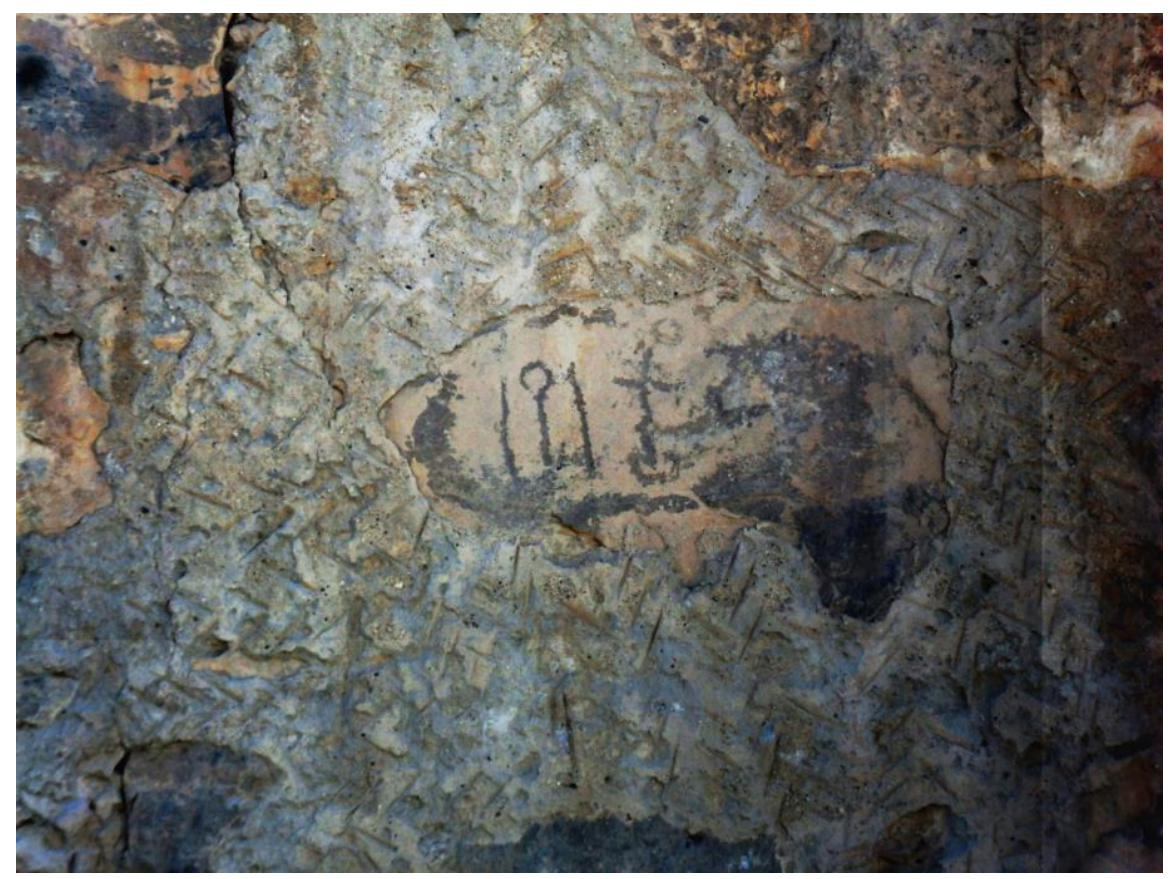

Fig. 2. The marks on the upstream dam (Campana, 2011).

Other few things had to be noted as a result of the survey recently done. On the blocks forming the sluices, there are not traces of tracks to lodge wooden/metallic plate meant to control the flux, as happened in the downstream dam. Seems improbable that there was no system of flux control especially because it exists on the second dam; probably recent restoration works obliterated the blocks with the tracks. A layer of plaster covered the entire upstream surface making it impermeable. Right now it is not possible to state if this layer is Umayyad or more recent. The entire surface is carved with small signs the purpose of which is not clear (Fig.2).The dikes found along the wadi presumably prevented the natural dispersion of the rainwater down slope. Moreover, they conveyed the water to the dam's basin in a controlled way, also diminishing the quantity of sediments falling from the slopes.

As we can see in the figure (Fig.3), rainfall has excavated the hill slope and has created parallel natural channels that damage the dike. The course of these channels is perpendicular to the dike, following the slope of the hill. Nowadays there is no maintenance meant to repair damages, as in the past, and dikes are losing their capacity of rainfall control.

About the ducts on the top of the dams, two explanations seem to be possible. The first one is that the ducts were constructed to lodge a series of wooden plates to improve the high of the dam in order to increase de capacity of the basin. The second is that the ducts were meant to lead overflow water to be used for domestic or drinking storage like in the case of the second dam. The problem is that, around the upstream dam, there are no remains of tanks or other hydraulic structures of storage. To be sure about the real origin of these remains further surveys are needed. 


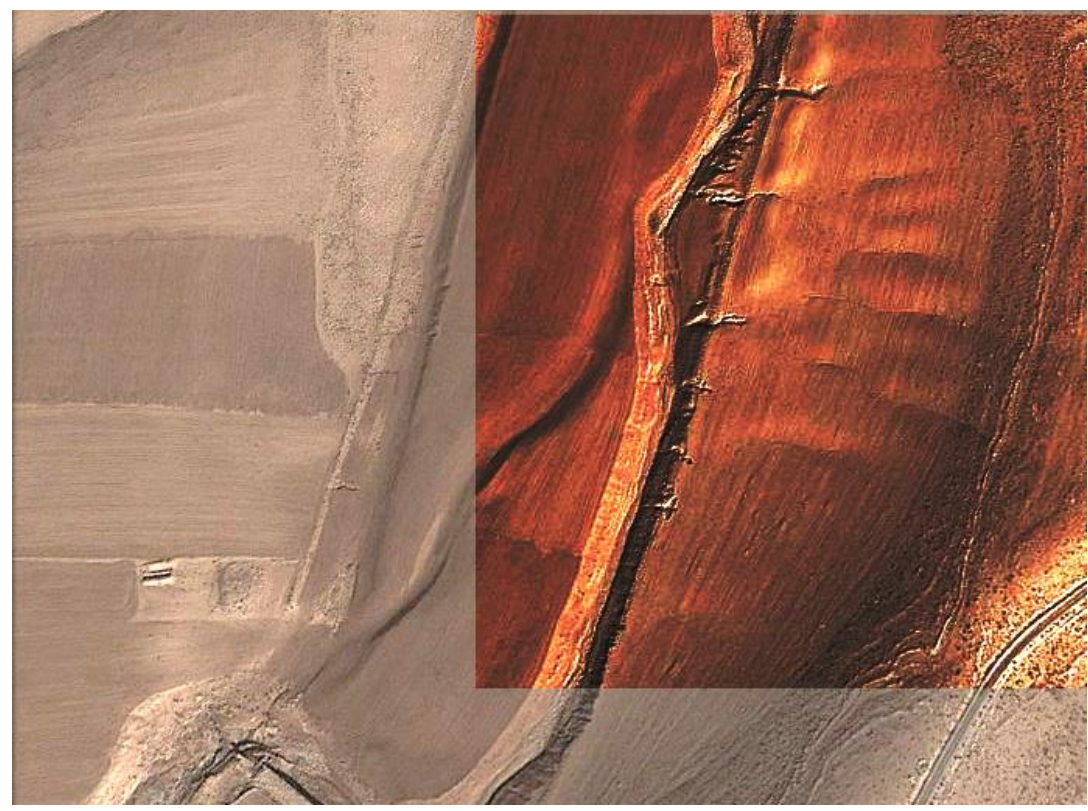

Fig. 3. Damages on the dike made by rainfall (Google Earth ${ }^{\mathrm{TM}}$ 2012).

The downstream dam, $187 \mathrm{~m}$ long, $4.10 \mathrm{~m}$ width and $7 \mathrm{~m}$ height, shows the same building techniques of the upstream one but with some slight differences (Fig.4). While the upstream façade show the same carved layer of impermeable plaster, the sluices devices are quite different. They were built with ashlar blocks (on the first dam, they are simple blocks), likely of reuse, and there are the tracks where the wooden/metal plates where lodged in order to control the water flux. Finally, the wall base in its downstream façade is mainly arranged with ashlar blocks reused from oldest buildings. ${ }^{4}$

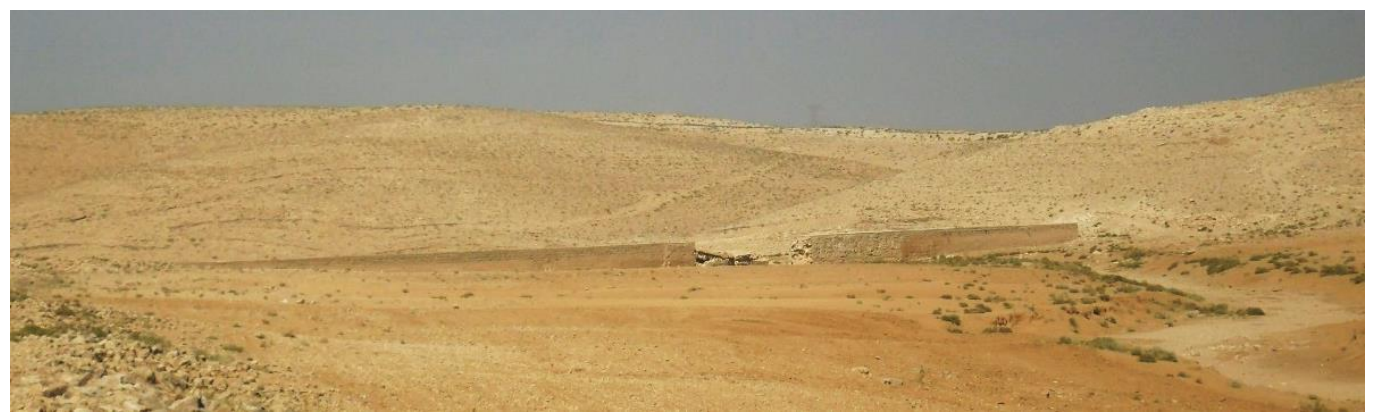

Fig. 4. The downstream dam (Campana, 2011).

Unlike the first dam, there is no trace on the upstream wall side of any sort of maintenance passage. On the downstream wall side, the "stepped" surface is less pronounced, probably because here the water pressure was less powerful. Even though there is a buttress. On the western side of the dam, there are remains of several structures that seem to be linked to it. They appear too big to be a simple guardian house. Anyway, one of the structures show the remains of a half-subterranean vaulted room, probably a tank. The bigger structure could be a farmers house with several storage rooms among which the tank on the first floor and partly underground. There are also traces of circular structures but their nature and function it is not clear: they could be remains of threshing floors. It is likely that the

${ }^{4}$ See note 3 
channel on the top of the dam lead the water in this area supplying the tank with clean water (the duct catch the water from the top of the basin while the sediments lies on the bottom and, probably, there was a settling basin near the tank).It is not usually easy to separate irrigation from domestic water supply because frequently both systems were derived from the same hydraulic works. Thus, a dam would provide water for both the town supply and the needs of the farmers (Hill, 2002). In this case, a canal is led out from the main hydraulic device and the water could be collected into the reservoir inside the house.

At the present day, the downstream dam shows a collapse in the middle, probably due to joint action of erosion and infiltration of the water. On the top of the dam, a layer of concrete obliterates the duct. All along, the structure is possible to see recent intervention of restoration.

All the similarity in the buildings techniques between these two dams and the eastern qasr of ' $\mathrm{Umm}$ al-Walid assure the contemporaneity of the structures (Bujard and Genequand 2001) even though it is possible, due the slight differences between the upstream dam and the downstream dam, that one of them was built in a second time, although not much more later.

\subsection{Jilat}

Another interesting case are the two dams at Jilat. At the time of his survey, King (King et al. 1981; 1992) was able to explore only downstream side of the dam because of the sedimentation. The dam is $28.85 \mathrm{~m}$ long and $5.80 \mathrm{~m}$ high in the central area and the structure is composed of well-worked calcareous-stone blocks and set in seventeen regularly stepped courses and with ashlar-worked outer faces. Every step is indented by $0.05 \mathrm{~m}$. At the north edge, the gorge reduces the height of the dam. Three rectangular buttresses, jutting $2.12 \mathrm{~m}$, from it reinforce the downstream wall of the dam. The composition of the dam's core is impossible to define but the buttresses have a filling made of rubble. Although there is graffiti, there is no trace of dating inscriptions. At the dam base, on the ground level, there are traces of a wall (not investigated) on both sides that could belong to sluices or canals. Jilat seems to show an important difference in purpose with the other dams. While in the other sites the dams was constructed to provide a reserve of water for a settlement and for irrigation, here there are no traces of fields, settlements or other buildings requiring such an amount of water; the dams seems to be constructed in the middle of nowhere.

It is possible that the structure was built to use this natural gorge to create a huge basin to supply the nomad tribes of this area and their flocks ${ }^{5}$. Supporting this theory there is the fact that, working on satellite images (Fig.5), no traces of agricultural works are appeared like, instead, at 'Umm al-Walid.

\footnotetext{
${ }^{5}$ The description and interpretation are based on the works of King et al. (1981)
} 


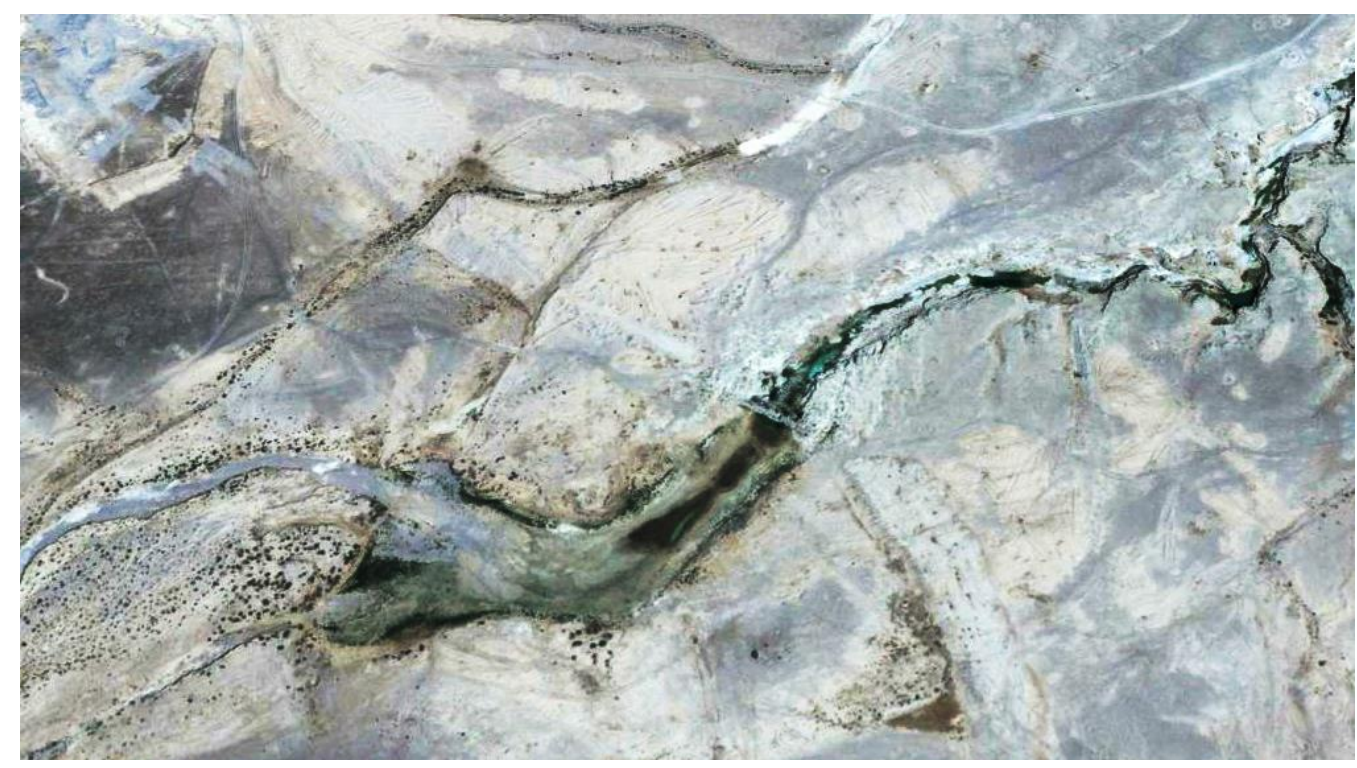

Fig. 5. The Jilat dam and the surrounding area (Google Earth $\left.{ }^{\mathrm{TM}} 2014\right)$.

This idea fit well with the Umayyad program that implied the enhancement of the water resources, especially in the eastern deserts area, to sustain the nomadic tribes on which they relay, at least in part, military. Nomadic tribes set their survival, and then their movements, on the natural water resources of a territory. More water meant an ally more powerful and always present on the near territory.

\section{4 'Umm al-Walid: a reconstruction about the possible irrigation system}

The goal of this chapter is to attempt to identify the irrigation systems linked with the hydraulic structures at 'Umm al-Walid, to better understand the Umayyad management of the territory.

The main way to proceed, at this time, is to compare the Umayyad remains with the modern management of this area, using photos and satellite imagery. This approach seems to be quite reliable since in this area the technological development, especially when linked with the agricultural practices, appear to be minimum and the portions of territory chosen to be cultivated are very likely the same used in ancient times i.e. the most fertile.

Through the observation of satellite imagery, modified to highlight different surface features, it is possible to notice a clear difference of color between the riverbed and the surrounding areas (Fig.6). The different coloration is due to the presence, more or less recent, of water (that make the riverbed much moister compared with the surrounding hills) and due to other signs of agricultural works.

The irrigated area were probably three. The first area of interest is the second meander, on the western side of the downstream dam, covered by modern fields. It is very likely that this area was cultivated also during the Umayyad period: the reconstructive hypotheses about the irrigation system suggest that the water was lead, on this downstream area, from the dam. 
The other two areas are located immediately beside the downstream façade of both dams: here there are remains, today almost disappeared, of irrigation channels. It is possible just make hypothesis about their operating principles. It seems very likely that these channels were meant to lead the water through the sediments and towards the fields. At this time, there are no evidence of channels leading the waters on the hills.

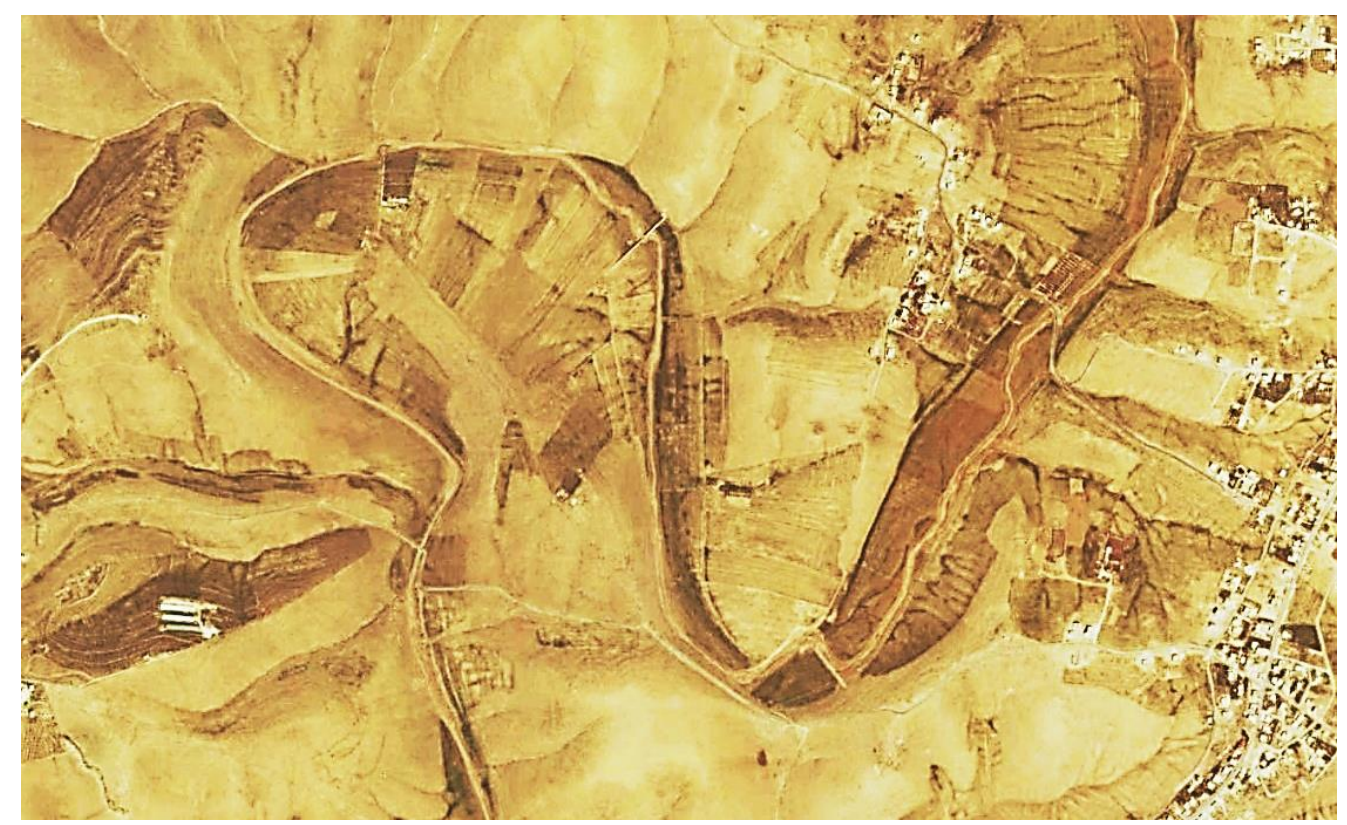

Fig. 6. Different field color around wadi al-Qanatir (Google Earth ${ }^{\mathrm{TM}}$ 2011).

Comparing with the modern techniques and other ancient sites $^{6}$, it is possible to suggest that a series of openings allowed to bring the water directly into the interested areas. Then the water flows towards the second dam creating the second basin and then the process restart.

Another area highlighted both by a darker color both by traces of fields and agricultural works is the first meander (on the western side of the first dam). However, if this area was irrigated, the only way to bring water there, would be through a channel not coming the near basin, too low respect it.

Using satellite imagery caught with Google Earth ${ }^{\mathrm{TM}}$, and working on them is possible to attempt to find the borders of these spaces (Fig.7).The idea is to make an hypothesis about the dimension of the three cultivated areas that have been identified. The first two include the areas directly on the downstream side of the dams (Fig.7, green areas); they measure respectively 2.1 ha (first dam) and 1.96 ha (second dam). The third involve the meander near the downstream dam (orange area) that covers 45.5 ha. The total surface identified as a irrigated area, by means of both dams, could have been of 49,56ha.

There is another problem. On the top of the two dams, there are remains of a duct, with an unclear function. On the downstream dam, as already mentioned, the duct appears to lead the water towards the near buildings (where there is also a tank). Indeed, near the first dam, there are no remains of structures (except for the small guardian house) that could be linked to the duct. Moreover, the gradient of the hill slope connected with the duct is considerable and seems improbable that the water was lead up there. It is possible to suppose

${ }^{6}$ Bayt al-Ashwal, Zafār see Barceló et al., 2000; 2003; Barceló \& Torró, 2000. 
that the duct was the origin of a channel running all along the south slope but, without further analysis, it is impossible to say.

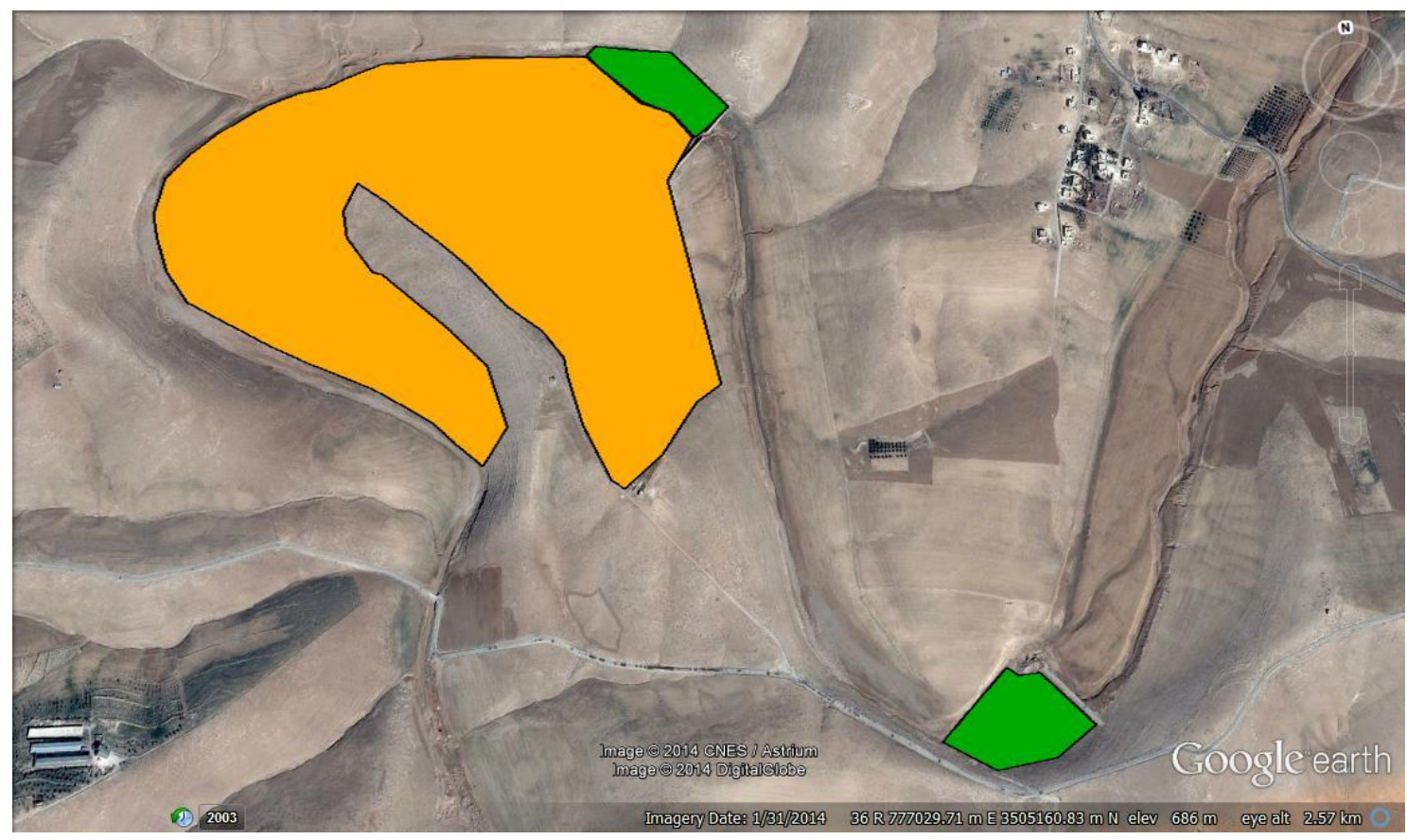

Fig. 7. The three cultivated areas (Google Earth ${ }^{\mathrm{TM}}$ 2011).

\section{Conclusions}

At this stage of the work, it is impossible to make exactly assertions about the Islamic irrigation and numerous questions are still unsolved. Which was the origin of these dams? Where did they take the "idea"? From the Romans, like the Harbaqa dam in Syria (Schlumberger, 1986), later re-used by the Umayyad, or from the Nabateans as seems to show the Khaybardam (Kay, 1978; Al-Sakkar, 1978)? Or from both of them? Did they use foreign architects or not? For how long they use these devices? And so on. The identification and measurement of the irrigated areas are based on the remains and the morphological pattern of the field systems located around the dams. This difficulty in the identification, highlight an important point: the scarce knowledge about this primary aspect of the agricultural policies of Umayyad caliphate.

The analysis of 'Umm al-Walid had revealed that the irrigated area were about 49, 56 ha. The Spanish Mission in Yemen found a similar situation. Comparing the data seems possible to state that at 'Umm al-Walid, like in Yemen (Barceló et al., 2000; 2003; Barceló Torró, 2000), the irrigated area was meant to the provision of the near settlement. Future works should aim to make new light about the Umayyad irrigation and hydraulic system in this region. 


\section{References}

Abu Shmais, A.I (2007): Notes on the old water system and the integrated of Jordan future, Studies in the history and archaeological of Jordan, 9:97-102.

Al-Sakkar, S. (1978):The dams of Taif - an observation and comment, Proceedings of the Seminar for Arabian Studies, 8:66-67.

Ballesteros Arias, P.; Kirchner, H.; Eiroa, J.; Fernández Mier, M.; Ortega Ortega, J.; Quirós Castillo, J.A.; Retamero, F.; Sitjes, E.; Torró, J. and Vigil-Escalera Guirado, A. (2010):Por una arqueología agraria de las sociedades medievales hispánicas. Propuesta de un protocolo de investigación, in Por una arqueología agraria: perspectivas de investigación sobre espacios de cultivo en las sociedades medievales hispánicas, BAR International Series, Archeopress, Oxford, 185-202

Barceló, M.; Kirchner, H. and Navarro, C.(1996):El agua que no duerme, Granada, Fundación El legado andalusí.

Barceló, M.; Kirchner, H. and Torró, J. (2000): Going around Zafār (Yemen), the Banū Ru'ayn field survey: hydraulic archaeology and peasant work, Proceedings of the Seminar for Arabian Studies, 30:27-39.

Barceló, M.; Ortega, J.; Piera, A.; Torró, J. (2003): The search for the Harara hasdādin the area of Zafār, Governatorate of Ibb, Yemen, Proceedings of the Seminar for Arabian Studies, 33:133-142.

Barceló, M. and Torró, J. (2003): The hydraulic set-up of Bayt al-Ashwal valley: a case study, Les Chaiers du CEFAS, 3:15-18; 129-132.

Bujard, J.; Genequand, D. and Trillen, W. (2001): Umm al-Walid et Khanaz-Zabib, deux établissements omeyyades en limite de désert jordanien, Travaux de la Maison de l'Orient Méditerranéen, 36:189-218.

Campana, I. (2012): Location, study and cataloguing of the Umayyad water supply systems in the SyroPalestinian territory, MA thesis (unpublished), Roma, La Sapienza Univeristà di Roma.

Herzfeld, E. (1921): Mshatta, Hira und Badiya: Die Mittellander des Islam und ihre Baukunst, Jabrbuch der Preuzischen Kunstsammlungen, 42:104-146.

Hill, D.R. and Al-Hassan, A.Y. (2002): Ingegneria, Storia della Scienza, Enciclopedia Italiana, 3/51:647-666.

Hoff, H.; Bonzi, C.; Joyce, B.; Tielbörger, K. (2011): A Water Resources Planning Tool for the Jordan River Basin, Water, 3:718-736.

Kamash, Z. (2006): Water Supply and Management in the Near East 63BC-AD636, PhD Thesis, University of Oxford.

Kay, S. (1978): Some ancient dams of the Hejaz, Proceedings of the Seminar for Arabian Studies, 8:68-80.

Kennedy, D. (1995): Water supply and use in southern Hauran, Jordan, Journal of Field Archaeology 22 (3):275-290.

King, G.R.D. - Lenzen, C. J. - Rollefson, G.O. (1983): Survey of Byzantine and Islamic Sites in Jordan, Second Season Report, 1981, Annual of the Department of Antiquities of Jordan, 27:385-436.

King, G.R.D. (1992): Settlement Patterns in Islamic Jordan: The Umayyads and their Use of the Land, Studies in the History and Archaeology of Jordan, 4:369-375. 
Kirchner, H. (2008): Archeologia degli spazi irrigati medievali e le loro forme di gestione sociale, in L'acqua nei secoli altomedievali, Atti delle LV Settimane, 1:471-503.

Schlumberger, D. (1986): Qasr el-Heir el-Gharbi, Paris.

\section{Other sources}

Aerial Photographic Archive for Archaeology in the Middle East, http://www.apaame.org/.

Natural Resources Authority of Jordan, http://www.nra.gov.jo/.

Discover Islamic Art, http://www.discoverislamicart.org/. 